\title{
PUBLIC INFORMATION DISCLOSURE IN GOOD GOVERNANCE FOR THE PREVENTION OF CORRUPTION IN INDONESIA (Study: The Implementation of Public Information Disclosure in LIPI)
}

\author{
Dewi Saraswati \\ Public Relations Officer of Informatics Research Center - LIPI \\ dewisarasaja@yahoo.com
}

\author{
ARTICLE INFORMATION \\ Article history: \\ Received April 15, 2016 \\ Revised Nov 08, 2017 \\ Accepted Dec 11, 2017 \\ JEL Classifications \\ M49; K42 \\ Key Words: \\ Public Information Disclosure; \\ LIPI; \\ Good Governance; \\ Prevention of Corruption
}

DOI:

10.21532/apfj.001.17.02.02.07

\begin{abstract}
The right to information is crucial because the more open the public scrutiny of the state administration, the more accountable the state administration is. Each public agency has the obligation to open public access to information relating to the Public Agency for the wider community, especially LIPI (Indonesian Institute of Sciences). Therefore, it is important to examine the implementation of the Public Information in LIPI in order to prevent acts of corruption. Based on the results of the research, it can be concluded that as the implementation of good governance, especially the embodiment of the principles of transparency in order to prevent acts of corruption, LIPI has conducted Public Information Disclosure. LIPI has provided Whistleblowing System (WBS) as a means to facilitate information providers who want to report allegations of corruption in LIPI. For general information requests related to LIPI can be accessed via http://wbs.lipi.go.id/
\end{abstract}

\section{Introduction}

One of the important elements in realizing an open state administration is the public's right to obtain information in accordance with the laws and regulations. The right to information becomes very important because the more open the organization of the state to be supervised by the public, the more accountable the administration of the state. The right to obtain information is also relevant to improve the quality of community engagement in public decision-making processes. Community participation and involvement will be useless without any guarantee of Public Information Disclosure (PID).

The existence of Law Number 14 of 2008 on Public Information Disclosure (PID) is very important as a legal basis relating to (1) the right of individual to obtain 
information; (2) the obligations of the Public Agency to provide and serve information requests promptly, timely, low / proportionate fees, and simple ways; (3) exceptions are strict and limited; (4) the obligation of the Public Agency to fix the documentation and information service system. Each Public Agency has an obligation to open access to public information relating to the Public Authority to the public at large.

The scope of the Public Authority in this Law includes the executive, judicial, legislative, and other state entities that derive funds from the State Budget / Regional Budget and includes non-government organizations, legal or non-legal entities, such as nongovernmental organizations, associations, and other organizations that manage or use funds that are partly or wholly derived from State Budget / Regional Budget, community contributions, and / or abroad.

Through the mechanism of the implementation of the principle of openness, it can create good governance, transparency, and accountability as the prerequisites for realizing essential democracy. By opening public access to information, it is expected that the Public Institution be motivated to be responsible and oriented towards the best service to the people. Thus, it can accelerate the realization of an open government as a strategic effort to prevent corruption, collusion and nepotism practices, and the creation of good governance (http:// www.kpk.go.id/id/layanan-publik/informasipublik/tentang-informasi-publik)

One of the public institutions, which serve as the organizer of the state by obtaining funds from the State Budget, is the Indonesian Institute of Sciences (or better known as LIPI). LIPI is a public institution that has an obligation to implement Public Information Disclosure (PID). Therefore, it is important to review the implementation of LIPI's PID in order to prevent acts of corruption.

\section{Research Method}

The methodology applied in preparing this paper is descriptive qualitative using secondary data, ie library material search in the form of legislation, dictionaries, books, presentation materials, news and writings contained in both papers and pages related to the implementation of LIPI's PID.

\section{Literature Review}

\section{Indonesian Institute of Sciences (LIPI)}

The formation of LIPI has a long historical background. After passing through several phases of scientific activity since the 16th century until 1956, the Indonesian government established the Indonesian Science Council (MIPI) through Law No. 6 of 1956. Its task was to guide the development of sciences and technology and gave consideration to the government in terms of science policy.

In 1962, the government established the Department of National Research Affairs (DURENAS) and placed MIPI in it with the additional task of establishing and nurturing several national research institutions. Until 1966, DURENAS status became the National

\section{Research Institute (LEMRENAS).}

Since August 1967, the government has dissolved LEMRENAS and MIPI with the Degree of President of Republic of Indonesia No. 128 of 196. After that, the government, based on MPRS Decree No. 18 / B / 1967 formed LIPI and accommodated all LEMRENAS and MIPI assignments into the institution. Its main tasks are (1) guiding the development of science and technology rooted in Indonesia in order to be utilized for the welfare of the Indonesian people in particular and mankind in general; (2) seeking scientific truths where scientific freedom, freedom of research, and freedom of speech are recognized and guaranteed, to the extent not in contradiction with Pancasila (Five Principles) and the 1945 Constitution; (3) preparing for the establishment of the 
Indonesian Academy of Sciences (since 1991, this main task has been handled by the State Minister for Research and Technology with Presidential Decree No. 179 of 1991).

Along with the development of national capability in the field of science and technology, science institutions in Indonesia also experienced growth and development. In response, observation and adjustment of basic tasks and functions and organizational structure of LIPI continue to be done. Among other things, the stipulation of Presidential Decree No.128 of 1967 dated August 23, 1967 amended by Presidential Decree No.43 of 1985. It was still further refined by Presidential Decree No. 1 of 1986 dated January 13, 1986 on the Indonesian Institute of Sciences. Finally, the improvement was done by stipulating Presidential Decree No. 103 of 2001.

LIPI, as the first, the largest and the best research institute in Indonesia, has the authority (www.lipi.go.id), including:

1. As an institution that holds scientific authorities in various aspects, such as providing data and scientific consideration for biodiversity conservation, as well as in the implementation of international conventions, such as the Convention on International Trade in Endangered Species of Wild Fauna and Flora (CITES) and the Convention on Biological Diversity (CBD).

2. Having role in providing scientific data and consideration in Spatial and Regional Plans (RTRW) as well as in establishing in-situ conservation areas using the concept of Biosphere Reserves as a Model of Area Management for Sustainable Development in Indonesia.

3. In accordance with Presidential Decree No. 13 of 1997 on National Standardization Agency and Presidential Decree no. 79 of 2001 on the National Standard Committee of Measure Units
(KSNSU), LIPI received a mandate to support the implementation of KSNSU duties and functions as a scientific technical manager of national standards for the unit of measure.

4. Based on the Regulation of the Ministry of Empowerment of State Apparatus and Bureaucratic Reform No. KEP / 128 / M.PAN / 2004 on the functional position of the researcher and the credit score, LIPI has the authority as the builder of functional position of national researcher and is responsible for assessing the accreditation of the researcher and supervising the quality including researcher ethics, both LIPI researchers and other ministries and institutions non LIPI.

\section{Public Information Disclosure (PID)}

Law Number 14 of 2008 on KIP that regulates the definition of information, public information, and public agencies listed in Article 1 and Chapter I of the Public Information Disclosure Law is as follows:

1. Information is explanations, statements, ideas, and signs that contain values, meanings, and messages, either data, facts or explanations that can be seen, heard, and read and presented in various packaging and format in accordance with the development of information technology and electronic or nonelectronic communication

2. Public Information is information generated, stored, managed, transmitted, and / or received by a public agency relating to the organizer and the operation of the state and / or organizer and the administration of other public agencies in accordance with this Legislation as well as other information relating to the public interest.

3. The Public Agency is executive, legislative, judicative institutions and 
other entities whose functions and duties relate to the administration of the state, which part or all of its funds are sourced from the State Budget and / or the Regional Budget, or non-government organizations whose part or all of their funds are sourced from the State Budget and / or Regional Budget, community contributions, and / or abroad.

Each Public Agency shall publish Public Information periodically. Information that must be made available and published periodically by a public agency is set in Article 9, Paragraph 2,: (1) Information relating to the Public Agency; (2) Information regarding the activities and performance of the relevant Public Agency; (3) Information on financial statements; and / or (4) Other information provided for in the laws.

\section{Good Governance}

Governance is defined as the mechanisms, practices and procedures of government and the citizens govern resources and solve public problems. In the concept of governance, the government only becomes one of the actors and is not always a decisive actor. The implications of the role of government as the provider of development, service, and infrastructure will shift into the driving force for the creation of an environment that is able to facilitate other parties in the community. Governance demands a redefinition of the role of the state, and this means that there is redefinition of the role of citizens. The demands on the citizens, among others, are to monitor the accountability of the government itself (Sumarto, 2003).

Good governance has become a crucial part in the discourse of the development of the bureaucratic paradigm and future development. The role of the implementation of the principles of good governance is to provide mechanisms and guidelines in providing balance for the stakeholders in fulfilling their respective interests (Dede Rosyada, 200).

From the various results reviewed by the Institute of State Administration (LAN), it can be concluded that there are nine fundamental aspects in the realization of good governance (LAN, 2000):

- Participation; each citizen has a voice in decision-making, either directly or in an intermediary legitimate institution representing his interests. Such participation is built on the basis of the legitimacy of association and constructive speaking and participation

- Rule of law; the legal framework should be fair and undertaken indiscriminately, especially the law for human.

- Transparency; transparency is built on the basis of validity of information flows, including the processes, institutions and information that are directly acceptable to those in need.

- Responsive; institutions and processes should try to serve every stakeholder.

- Consensus Orientation; good governance intermediates different interests to gain the best option for broader interests, both in policies and procedures.

- Equity; all citizens, both men and women have the opportunity to improve or maintain their welfare.

- Effectiveness and efficiency; processes and institutions produce according to what has been outlined by using the best available resources.

- Accountability; decision makers in government, the private sector and civil society are accountable to the public and stakeholder institutions. This accountability depends on the organization and nature of the decision made, whether the decision is for internal or external purposes of the organization.

- Strategic vision; the leaders and the public 
should have a broad and far-reaching perspective of good governance and development in line with what is required for such development.

\section{The Implementation of LIPI's Public} Information Disclosure to Achieve Good Governance for the Prevention of Corruption

\section{in Indonesia}

Various approaches to combating corruption that have been implemented by the Government of Indonesia are more likely to be repressive. The paradigm that develops in society is that the approaches are considered an effective effort to generate deterrent effect.

The existence of community needs, that is, the needs for information through information disclosure that must be met by the Government. This has been guaranteed by Law Number 14 of 2008 on Public Information Disclosure (PID Law) which until now still needs to be implemented thoroughly and in good quality. Easy and effective access to information for the public is important. As a form of the fulfillment of the Government to the public, the government issued Presidential Instruction (Inpres) No. 2 of 2014 on the action of prevention and eradication of corruption, in which one of the main indicators of its success is Public Information Disclosure (PID).

As an effort to implement Public Information Disclosure, LIPI has provided a facility in the form of portal www.informasi. lipi.go.id. This facility is provided to facilitate the public to submit a request for public information in accordance with the mandate of Law No. 14 of 2008 on Public Information Disclosure effective from May 1, 2010. With this law the public is entitled to request public information that is managed by a public agency such as LIPI in accordance with the applicable provisions. LIPI strongly encourages all requests for information through PID Online, and cannot guarantee prime services for applications through other channels (e-mail, phone, fax, etc.).

The Head of LIPI has appointed Information and Documentation Management Officer (better known in Indonesia as PPID) in each work unit. So, all PID implementations must be made online through this facility, and directly addressed to the relevant public information management work unit through each PPID after registering. The applicant is only one time to register, and can use it for life to all LIPI work units.

In accordance with Public Information Disclosure PID Law, LIPI has performed the obligation to open the recapitulation of public information request periodically, where every request for public information is processed within 10 (ten) working days. The whole recapitulation of LIPI public information request can be seen at www.informasi.lipi. go.id.

In achieving good governance to prevent the acts of corruption, LIPI has opened and implemented the Whistle-blowing System (WBS) which serves as a means to facilitate informers who want to report an indication of corruption act in LIPI. For a request of general information related to LIPI, the individual can access the means in accordance with applicable regulations. The identity of the reporting person as a whistleblower is guaranteed confidentiality. LIPI's WBS is focused on the material being reported, and not on who reports. The means that can be used by community is http://wbs. lipi.go.id.. This is implemented as an effort to encourage the involvement of all community components in preventing and eradicating corruption through LIPI's PID.

The Complaint Statistics in 2015 can be seen as follows (http://pengaduan.lipi.go.id/ : 
Dewi Saraswati : Public information disclosure in good governance for.....

Page 193-201

\ Request

\Response Time Average
: 0 not yet confirmed

10 confirmed

0 accepted

1 rejected

: $\mathbf{3 . 4}$ working days

$\mathbf{0 . 0 \%}$ according to the standard of 10 working days

In addition, this facility also presents Government Agency's Performance Accountability Reports ofLIPI through http://www2.lipi.go.id/www.cgi?kinerja. LIPI's performance achievements in 2015 can be seen in the following table:

Table of LIPI's Performance Achievement in 2015

\begin{tabular}{|c|c|c|c|c|}
\hline \multirow{2}{*}{ WORK UNIT } & \multicolumn{4}{|c|}{ ACHIEVEMENT (\%) } \\
\hline & $\mathbf{I}$ & II & III & IV \\
\hline - Head of LIPI & - & - & - & - \\
\hline - Deputy Head of LIPI & 178.1 & 110.6 & 110.5 & 151.4 \\
\hline - Inspectorate & 83.2 & 88.2 & 90.5 & 98.0 \\
\hline - Research Center for the Development of Science and Technology & 181.4 & 171.9 & 160.9 & 200.1 \\
\hline - Center for Coaching, Education, and Training of Researchers & 98.9 & 103.0 & 98.1 & 105.5 \\
\hline - Main Secretary & 0.0 & 0.0 & 0.0 & 0.0 \\
\hline - Bureau of Planning and Finance & 110.6 & 91.7 & 99.7 & 99.0 \\
\hline - Bureau of Organization and Human Resources & 106.9 & 91.8 & 79.9 & 108.5 \\
\hline - Bureau of Cooperation, Law, and Public Relation & 120.0 & 98.2 & 104.8 & 108.8 \\
\hline - General Bureau & 99.2 & 100.0 & 98.4 & 123.2 \\
\hline - Deputy of Earth Sciences & 120.2 & 127.5 & 145.3 & 100.0 \\
\hline - Research Center for Geo-technology & 225.3 & 198.0 & 98.9 & 181.2 \\
\hline - Research Center for Oceanography & 66.0 & 120.0 & 157.3 & 118.4 \\
\hline - Research Center for Limnology & 131.4 & 91.2 & 102.3 & 101.6 \\
\hline - Research Center for Metallurgy and Materials & 764.9 & 670.7 & 611.1 & 392.0 \\
\hline - $\underline{\text { Research Center for Deep Sea }}$ & 132.5 & 210.9 & 399.9 & 208.7 \\
\hline - Technical Implementation Unit for Bitung Marine Biota Conservation & 150.0 & 212.5 & 142.0 & 197.3 \\
\hline - Technical Implementation Unit for Biak Marine Biota Conservation & 0.0 & 157.1 & 120.0 & 123.0 \\
\hline
\end{tabular}


- Technical Implementation Unit for Tual Marine Biota Conservation

$100.0140 .0159 .5 \quad 129.1$

- Technical Implementation Unit for Human Resource Competency

Development of Oceanography of Pari Island

$488.2219 .5201 .6 \quad 244.6$

- Technical Implementation Unit for the Development of Sea Bio-industry of Mataram

133.3150 .6209 .8219 .0

- Technical Implementation Unit for Mining Engineering Test of JampangKulon

- Technical Implementation Unit for Mining Engineering Test and Disaster Mitigation of Liwa

- Technical Implementation Unit for Karangsambung Earth information and Conservation

$109.364 .5 \quad 69.3 \quad 90.0$

-Deputy of Life Sciences

- Research Center for Biology

- Research Center for Biotechnology

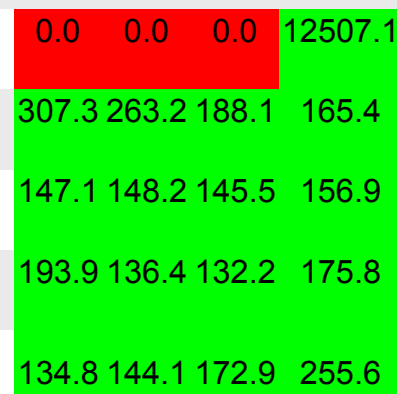

- Technical Implementation Unit for Cibodas Botanical Gardens Conservation Center

134.8144 .1172 .9255 .6

- Technical Implementation Unit for Purwodadi Botanical Gardens

Conservation Center

- Technical Implementation Unit for EkaKarya Bali Botanical Gardens Conservation Center

- Deputy of Engineering Science

$156.7147 .9153 .8 \quad 422.5$

- Research Center for Physics

- $\underline{\text { Research Center for Chemistry }}$

- $\underline{\text { Research Center for Informatics }}$

- Research Center for Electric Power and Mechatronics

- Research Center for Electronics and Telecommunications

- Center for Appropriate Technology Development

- Technical Implementation Unit for Ranggamalela Signal and Navigation Development 
Dewi Saraswati : Public information disclosure in good governance for.....

Page 193-201

\begin{tabular}{|c|c|c|}
\hline - Research Center for Mineral Technology & 100.088 .3126 .0 & 128.0 \\
\hline - Deputy of Social Sciences and Humanity & 90.2104 .496 .0 & 31.6 \\
\hline - Research center for Society and Culture & 103.8134 .6136 .0 & 148.7 \\
\hline - Center for Economic Research & 131.2118 .0112 .5 & 103.8 \\
\hline - Population Research Center & 98.8171 .2177 .2 & 125.6 \\
\hline - Center for Political Research & $0.0 \quad 0.0 \quad 0,0$ & 100.0 \\
\hline - Research Center for Regional Resources & 146.7121 .9108 .9 & 148.5 \\
\hline - Deputy for Scientific Services & 137.1111 .7112 .2 & 123.0 \\
\hline - $\underline{\text { Research Center for Metrology }}$ & 121.3113 .9112 .0 & 119.8 \\
\hline - $\underline{\text { Research Center for Quality System and Testing Technology }}$ & 107.8116 .0137 .7 & 141.3 \\
\hline - Center for Documentation and Scientific Information & 149.5162 .1172 .2 & 144.6 \\
\hline - Innovation Center & 100.0108 .6112 .5 & 132.8 \\
\hline - Technical Implementation Unit for Bandung Instrumentation Developmen & 109.8172 .2133 .0 & 128.3 \\
\hline $\begin{array}{l}\text { - Technical Implementation Unit for Bandung Information Technology } \\
\underline{\text { Center }}\end{array}$ & 109.0121 .3181 .0 & 119.2 \\
\hline $\begin{array}{l}\text { - Technical Implementation Unit for Media and Reproduction Center (LIPI } \\
\text { Press) Jakarta }\end{array}$ & 115.7174 .0210 .8 & 167.7 \\
\hline Performance Achievement Accumulation (\%) & 140.6142 .7142 .4 & 381.8 \\
\hline
\end{tabular}

LIPI has established Public Information Disclosure (PID) as a means of information disclosure to the public to prevent corruption. The existence of LIPI's PID is expected to give understanding to the public to get their right as citizen in the matter of information disclosure. PID can reduce the number of corruption, because if all communities play an active role in policy making, the corruption can be prevented as early as possible. Corruption is committed not only because of a chance and desire, but also because of the lack of supervision from the community.

One of the parties that play an important role in the implementation of PID is the public relations division which is obliged to provide information to the public. This means that public relations officials now play an important role in ensuring citizens' rights to information, increasing public participation in policy making, and running clean, transparent and effective governance. Likewise, LIPI has optimized the role of functional stakeholders of public relations existing throughout the work units under LIPI through Information and Documentation Provider Officer (PPID) at each work unit.

\section{CONCLUSION}

As the implementation of good governance, especially the realization of the principle of transparency in an effort to prevent corruption acts, LIPI has implemented Public Information Disclosure (PID). LIPI has opened 
the Whistle-blowing System (WBS) as a means to facilitate informers who want to report an indication of corruption act in LIPI. To request for general information related LIPI, the informer can access http://wbs.lipi.go.id.

\section{REFERENCES}

Dede Rosyada Dkk, Demokrasi, Hak Asasi Manusia Dan Masyarakat Madani, (Jakarta: ICCE UIN Syarif Hidayatullah, 2000), hal 182

http://www.kpk.go.id/id/layanan-publik/ informasi-publik/tentang-informasipublik

www.informasi.lipi.go.id.

http://www.lipi.go.id

http://wbs.lipi.go.id

http://pengaduan.lipi.go.id/

http://www2.lipi.go.id/www.cgi?kinerja

Instruksi Presiden (Inpres) Nomor 2 Tahun 2014 tentang Aksi Pencegahan Dan Pemberantasan Korupsi

Lembaga Administrasi Negara (LAN) RI. 2000. Badan Pengawasan Keuangan dan Pembangunan (BPKP), Pengukuran Kinerja Instansi Pemerintah: Modul Sosialisasi Sistem Akuntabilitas Kinerja Istitut Pemerintah. Lembaga Administrasi Negar (LAN) RI.

Keppres No. 103 Tahun 2001 tentang Lembaga Ilmu Pengetahuan Indonesia

Sumarto Hetifa $\mathrm{Sj}$, Inovasi, Partisipasi dan Good Governance , (Bandung: Yayasan Obor Indonesia, 2003), hal 1-2

Undang-Undang Nomor 14 tahun 2008 tentang Keterbukaan Informasi Publik 
Dewi Saraswati : Public information disclosure in good governance for.....

Page 193-201 